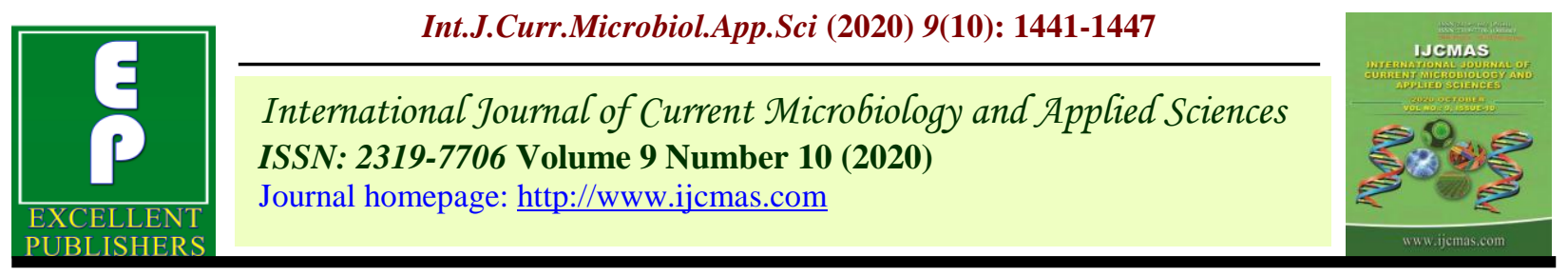

Original Research Article

https://doi.org/10.20546/ijcmas.2020.910.171

\title{
Molecular Detection of Cucumber Mosaic Virus in Bell Pepper (Capsicum annuum L.)
}

\author{
Tanvi $^{1}$, Anil Handa ${ }^{{ }^{*}}$ and Shelly Kapoor ${ }^{2}$ \\ ${ }^{1}$ Department of Biotechnology, ${ }^{2}$ Department of Plant Pathology, Dr YS Parmar University of \\ Horticulture and Forestry Nauni-173230, Solan, Himachal Pradesh, India \\ *Corresponding author
}

\section{A B S T R A C T}

Keywords

Bell pepper,

Cucumber mosaic

virus, incidence and RT-PCR

Article Info

Accepted:

12 September 2020

Available Online:

10 October 2020
Extensive surveys were conducted to determine the incidence and distribution of Cucumber mosaic virus (CMV) infecting bell pepper (Capsicum annuum L.) between 2017- 2019 indifferent capsicum growing localities of Solan district in Himachal Pradesh. Symptoms on infected plants included mottling, mosaic, mid vein distortion, chlorotic spots, leaf deformation, puckering and stunting with disease incidence ranging between 9.3 to 71.3 percent. The identity of the causal virus was established on the basis of symptomatology and molecular assays. Primers designed against coat protein $(\mathrm{CP})$ gene resulted in obtaining a desired amplicon of $\sim 162 \mathrm{bp}$ confirming the isolate to be of Cucumber mosaic virus.

\section{Introduction}

Capsicum(Capsicum annuum L.), a member of Solanaceae family, is an important vegetable and spice crop grown throughout the world. Owing to its high nutritive value and multiple uses in food industry it has emerged as an important cash crop for farmers in major capsicum growing countries like China, India, Korea, Nigeria, Malaysia, Indonesia and Mexico. In India, it is cultivated over an area of 34,000 ha with an annual production of 4.87 lakh MT (Anonymous, 2018). The major capsicum producing states in India are Andhra Pradesh,
Uttarakhand, Himachal Pradesh, West Bengal, Karnataka, Maharashtra, Tamil Nadu and Uttar Pradesh. In Himachal Pradesh, capsicum is the third most important vegetable crop grown after pea and tomato and occupies an area of 2.59 thousand ha with an annual production and productivity of 59.52 thousand MT and $23.10 \mathrm{MT} / \mathrm{ha}$, respectively (Anonymous, 2018).

Capsicum has immense export potential in food processing sector, the crop is however a victim of several biotic and abiotic stresses that affect its productivity and is susceptible to a number of bacterial, fungal and viral 
pathogens causing considerable economic losses. Among these, viral diseases attract attention since they result in considerable production constraints as they are difficult to control and also affect yield and quality of the crop (Nono-womdin, 2001). Around sixty eight viruses are known to infect capsicum naturally (Pernezny et al., 2003) and cucumber mosaic virus is most devastating among these as it has a wide host range including cucurbits, Leguminous and ornamental plants besides Solanaceous crops and is readily transmitted in a non-persistent manner by more than 75 species of aphids (Zitikaite and Staniulis, 2006; Berniak et al., 2009). Capsicum is grown on large scale in Solan district of Himachal Pradesh and routine surveys conducted in different capsicum growing localities revealed typical symptoms of viral etiology. Symptoms expressed on infected capsicum plants were mottling, mosaic, chlorotic spots, mid vein distortion, leaf deformation, vein banding, puckering and stunting of plants. Keeping in view the widespread occurrence and severity of symptoms, the investigations were conducted to establish the exact identity of the causal virus based on RT-PCR molecular assays.

\section{Materials and Methods}

\section{Surveys for the presence of CMV}

Surveys were conducted in major capsicum growing areas of Solan district of Himachal Pradesh during active cropping seasons of 2017, 2018 and 2019 to record the occurrence and distribution of viral diseases on the basis of visual symptoms.Percent disease incidence was calculated by choosing random locations in the fields and counting number of healthy and diseased plants after recording observations on symptoms as per the formula given below (McKinney, 1923):

$$
\text { Disease incidence }(\%)=\frac{\text { Number of plants infected }}{\text { Total number of plants }} \times 100
$$

\section{Molecular characterization}

Total RNA was extracted from leaves of symptomatic bell pepper plants suspected to be infected with cucumber mosaic virus by employing Real Genomics Total RNA Extraction Kit (Real Biotech Corporation, Taiwan). After confirming the presence of total RNA on agarose gel, cDNA synthesis was performed by using Thermo Scientific / Fermentas first strand cDNA synthesis kit protocol using random hexamers. PCR assay was carried out for the amplification of cDNA strand according to the protocol of Sambrook and Russel (2001).CP gene primer pair CMV 1F (GGCTGCAGTGGTCTCCTT) and CMV 1R (GAGTCGAGTCATGGACAAATC) was used to amplify coat protein gene (Sharma et al., 2016) and a desired amplicon obtained was run on 1.0percentagarose gel.

The reaction components and conditions of PCR were standardized and presented in Table 1 and 2. Size of bands on the gel was determined by simultaneously running $100 \mathrm{bp}$ marker ladder (Real Biotech Corporation, Taiwan) with the PCR product. The electrophoresed gel was then analysed under Gel Documentation System (Gel Doc XR+, BIO-RAD, USA).

\section{Results and Discussion}

\section{Survey and symptomatology}

Incidence of CMV was recorded to unravel the occurrence and distribution of CMV infecting capsicum in Solan district. Naturally infected pepper plants under field conditions exhibited mottling, mosaic, mid vein distortion, leaf deformation, vein banding and puckering symptoms (Figure 1). Such type of symptoms have been reported to be associated 
with cucumber mosaic virus infecting capsicum plants by a number of workers (Ben chaim et al., 2001;Bhadramurthyet al., 2009;Iqbal et al., 2011;Rahmanet al., 2016;Kapoor et al., 2018;Gunes and Gumus, 2019).

Virus incidence on capsicum plants in different localities surveyed in Solan district revealed significant variation in the intensity of occurrence. The incidence of CMV ranged from 9.3 to71.3 during the period of survey (Table 3).

Maximum disease incidence was recorded at Salogra (71.3 percent) followed by Amber (62.8 percent) whereas minimum incidence of 9.3 percent was recorded at Experimental farm of the Department of Soil Science, YSP UHF Nauni.

\section{Molecular characterization}

Thirty virus isolates which tested positive in DAS-ELISA for cucumber mosaic virus were subjected to RT-PCR based molecular assays. Total RNA extracted was examined on 1.0 percent agarose gel (Figure 2) and cDNA was later synthesized from total RNA. The amplification of desired amplicon $\sim 162$ bp of CMV-CP gene was obtained at annealing temperature of $55^{\circ} \mathrm{C}$ for 40 seconds with 35 cycles. The PCR product was examined by electrophoresis on 1.0percentagarose gel and compared with 100 bp marker ladder on lane $\mathrm{M}$ (Figure 3). The results were in conjunction with the findings of many workers on the use of RT-PCR for the detection of CMV in bell pepper (Eiras et al., 2004; Khan et al., 2006; Zitikaite and Samuitiene, 2009; Kapoor, 2012; Azizan et al., 2017; Ramesh and Sreenivasulu, 2018).

Table.1 Components of PCR reaction mixture for amplification of cucumber mosaic virus (CMV) coat protein gene

\begin{tabular}{|c|c|c|}
\hline Components (stock concentration) & Reaction volume & Final concentration \\
\hline cDNA & $2.0 \mu \mathrm{l}$ & $2.0 \mu 1$ \\
\hline Forward Primer (CMV-1F) & $1.0 \mu l$ & $10 \mathrm{mM}$ \\
\hline Reverse Primer (CMV-1R) & $1.0 \mu \mathrm{l}$ & $10 \mathrm{mM}$ \\
\hline 10X Reaction Buffer & $2.5 \mu l$ & $1 X$ \\
\hline dNTP mix (10mM) & $2.5 \mu 1$ & $2.5 \mathrm{mM}$ \\
\hline Taq DNA polymerase $(5 \mathrm{U} / \mu \mathrm{l})$ & $0.2 \mu 1$ & $1 \mathrm{U} / \mu \mathrm{l}$ \\
\hline Nuclease free water & $10.8 \mu 1$ & - \\
\hline Total & $20.0 \mu \mathrm{l}$ & \\
\hline
\end{tabular}

Table.2 PCR cycle set up for amplification of cucumber mosaic virus (CMV) coat protein gene

\begin{tabular}{|l|c|c|c|}
\hline Steps & Temperature $\left({ }^{\circ} \mathbf{C}\right)$ & Duration minutes) & No. of cycles \\
\hline Initial Denaturation & 94 & $4: 00$ & \\
\hline Denaturation & 94 & $0: 15$ & \\
\hline Annealing & 55 & $0: 40$ & 35 \\
\hline Extension & 72 & $1: 00$ & \\
\hline Final Extension & 72 & $5: 00$ & \\
\hline
\end{tabular}


Table.3 Incidence of virus diseases on capsicum at different locations of Solan

\begin{tabular}{|c|c|c|c|c|}
\hline S.No. & Locations & \multicolumn{3}{|c|}{ Incidence (\%) 201720182019} \\
\hline 1. & Wakna & 29.8 & 31.8 & 30.1 \\
\hline 2. & Kot & 35.0 & 33.1 & 32.9 \\
\hline 3. & Kiari & 30.2 & 29.5 & 36.2 \\
\hline 4. & Chail & 49.4 & 50.2 & 48.1 \\
\hline 5. & Salogra & 69.7 & 71.3 & 70.0 \\
\hline 6. & Guthan & 13.4 & 15.9 & 15.7 \\
\hline 7. & Panrot & 41.4 & 38.3 & 40.0 \\
\hline 8. & Shamber & 39.0 & 42.0 & 41.8 \\
\hline 9. & Dhar & 25.9 & 30.1 & 28.4 \\
\hline 10. & Jaunaji & 40.2 & 34.9 & 37.8 \\
\hline 11. & Ashwinikhadd & 44.9 & 41.5 & 42.6 \\
\hline 12. & Saproon & 10.5 & 13.4 & 16.0 \\
\hline 13. & Lavighat & 47.0 & 39.6 & 46.8 \\
\hline 14. & Kaylar & 35.2 & 29.4 & 33.3 \\
\hline 15. & Deothi & 40.2 & 41.9 & 37.0 \\
\hline 16. & Subathu & 30.1 & 26.8 & 26.7 \\
\hline 17. & Kanda & 17.4 & 19.9 & 19.6 \\
\hline 18. & Basal & 32.8 & 36.5 & 35.0 \\
\hline 19. & Kariyali & 24.8 & 25.1 & 23.9 \\
\hline 20. & Amber & 62.8 & 61.3 & 62.0 \\
\hline 21. & Koti & 58.9 & 60.1 & 60.2 \\
\hline 22. & Dharja & 48.4 & 39.6 & 46.6 \\
\hline 23. & Shamrod & 52.8 & 49.2 & 51.2 \\
\hline 24. & Oachghat & 31.1 & 33.9 & 31.3 \\
\hline 25. & Gadhog & 39.6 & 44.8 & 47.1 \\
\hline 26. & Galyan & 33.5 & 32.4 & 32.9 \\
\hline 27. & Molo & 25.8 & 29.5 & 27.6 \\
\hline 28. & Koti & 21.0 & 20.5 & 19.0 \\
\hline 29. & Jatoli & 40.6 & 42.1 & 39.1 \\
\hline 30. & Tatool & 15.6 & 11.9 & 12.2 \\
\hline 31. & Bhajol & 11.8 & 10.6 & 10.8 \\
\hline 32. & Sultanpur & 27.3 & 28.6 & 29.8 \\
\hline 33. & Diggal & 31.9 & 29.5 & 34.5 \\
\hline 34. & Ramshehar & 21.3 & 22.7 & 21.1 \\
\hline 35. & Manpura & 26.5 & 28.5 & 32.9 \\
\hline 36. & Sandholi & 10.8 & 11.9 & 11.7 \\
\hline 37. & Naganji & 55.9 & 53.4 & 53.1 \\
\hline 38. & $\begin{array}{l}\text { Experimental Farm of department } \\
\text { of Vegetable Science, Nauni }\end{array}$ & 29.1 & 34.1 & 33.8 \\
\hline 39. & $\begin{array}{l}\text { Experimental Farm of department } \\
\text { of Seed Science and Technology, } \\
\text { Nauni }\end{array}$ & 29.6 & 28.7 & 27.9 \\
\hline 40. & $\begin{array}{l}\text { Experimental Farm of department } \\
\text { of Soil Science, Nauni }\end{array}$ & 11.5 & 10.5 & 9.3 \\
\hline
\end{tabular}


Fig.1 Symptoms on infected capsicum plants a) Mottling and puckering b) mid vein distortion c) Mosaic d) Diffused chlorotic spots

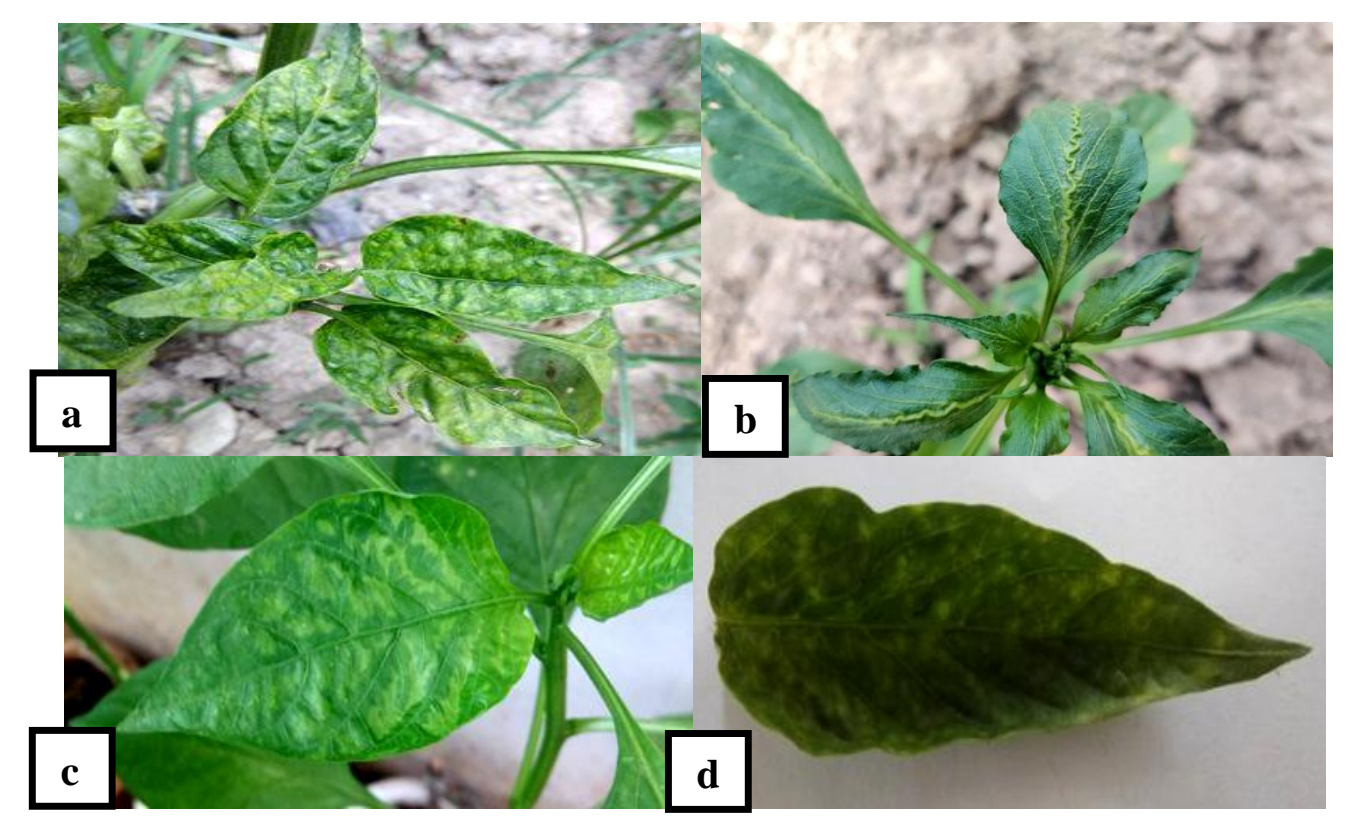

Fig.2 RNA bands fractionated on 1.0 agarose gel

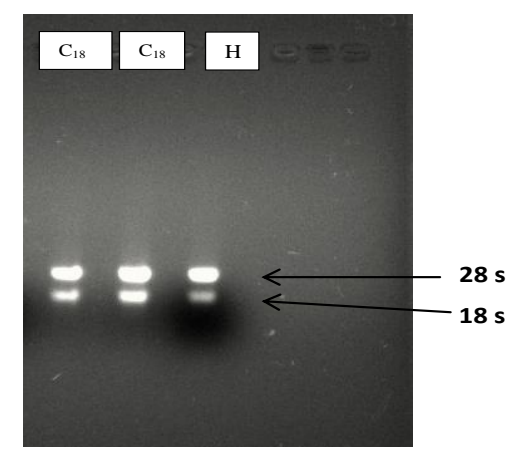

Fig.3 PCR product on 1.0 percent agarose gel

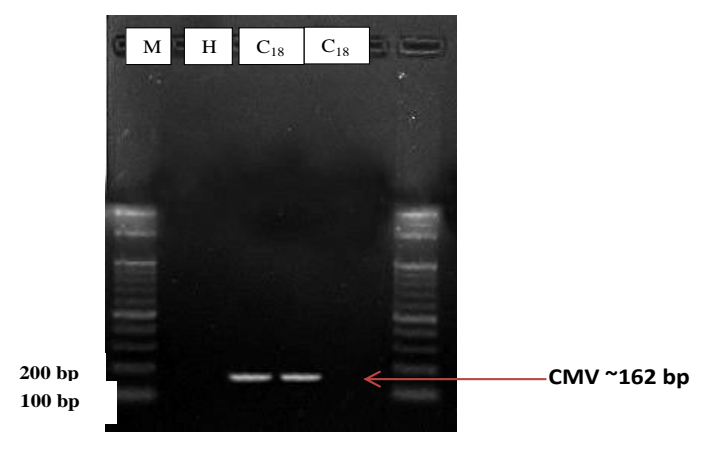


In conclusion the cucumber mosaic virus is fast emerging as a potential threat to the Solanaceous vegetable crops in Himachal Pradesh and the present investigations have identified the virus on the basis of RT-PCR molecular assays. The studies have opened a channel for conducting future studies on cucumber mosaic virus with the objective of understanding the dynamics of this devastating virus in Solanaceous crops.

\section{References}

Anonymous. 2018. http://www.nhb.org/

Azizan, N.H., Abidin, Z.A.Z., Phang, I.C. 2017. Study of cucumber mosaic virus gene expression in Capsicum annuum. Sci. Herit. J. 1: 29-31.

Ben Chaim, A., Grube, R., Lapidot, M., Jahn, M. and Paran, I. 2001. Identification of quantitative trait loci associated with resistance to cucumber mosaic virus in Capsicum annuum. Theor. Appl. Genet. 102:1213-20.

Berniak, H., Malinowski, T. and Kaminska, M. 2009. Comparison of ELISA and RT-PCR assays for detection and identification of cucumber mosaic virus (CMV) isolates infecting horticultural crops in Poland. J. Fruit Ornam. Plant Res. 17: 5-20.

Bhadramurthy, V., George, A., Bhat AI, Shiva KN. 2009. Coat protein gene sequence studies suggest that Cucumber mosaic virus infecting paprika (Capsicum annuum L.) in India belongs to subgroup IB. Arch. Phytopathol. Pflanzenschutz. Pp. 85763.

Eiras, M., Boari, A., Colariccio, A. and Chaves, A.L.R. 2004. Characterization of isolates of the cucumovirus Cucumber mosaic virus present in Brazil. J. Plant Pathol. 86: 61-69.

Gunes, N. and Gumus, M. 2019. Detection and Characterization of Tomato spotted wilt virus and Cucumber mosaic virus on Pepper Growing Areas in Antalya. J. Agric. Sci. 25:259-71.

Iqbal, S., Ashfaq, H. and Shah, H. 2011. Biological characterization of Pakistani isolates of Cucumber mosaic virus. Pak. J. Bot. 43: 3041-47.

Kapoor, P. 2012. Detection of cucumber mosaic virus in bell pepper crop from Himachal Pradesh. Plant Dis. Res. 27:71-78.

Kapoor, S., Sharma, A. and Handa, A. 2018.Correlation between Symptoms and ELISA for the Detection of Cucumber Mosaic Virus in Bell Pepper. Int. J. Curr. Microbiol. App. Sci. 7: 400-06.

Khan, S.M., Raj, S.K., Bano, T. andGarg, V.K. 2006.Incidence and management of mosaic and leaf curl diseases in cultivars chilli (Capsicum annuum L.). J. Food Agric. Environ. 4:171-74.

McKinney, H.H. 1923. Influence of soil temperature and moisture on infection of wheat seedlings by Helminthosporium sativum. J. Agric. Res. 26-195-210.

Nono-Womdin, R., Swai, I.S., Chadha, M.L., Gebre Selassie, K. and Marchoux, G. 2001. An overview of major virus diseases of vegetable crops in Africa and some aspects of their control. Plant Virology in Sub Sahara of Africa 213-30.

Pernezny, K.I., Roberts, P.D., Murphy, J.F. and Goldberg, N.P. 2003. Compendium of pepper diseases. St. Paul, Minnesota, USA APS Press pp. 88.

Rahman, M.S., Akhter, M.S., Alam, M.M., Pervin, N. and Akanda, A.M. 2016. Prevalence of Cucumber Mosaic Virus and its impact on growth and yield of different chili cultivar. Bull. Inst. Trop. Agr., 39: 65-74. 
Ramesh, B. and Sreenivasulu, P. 2018. Detection of cucumber mosaic virus in brinjal and chilli by RT-PCR. Int. $J$. Pharm. Biol. Sci., 8:128-31.

Sambrook, J. and Russel, D.W. 2001. Molecular cloning-A Laboratory Manual. Cold Spring Harbor Laboratory Press, New York. 2231p.

Sharma, P.N., Patiyal, K., Rialch, N. and Rana, D. 2016. Association of virus complex with capsicum under protected cultivation in Himachal Pradesh and implications in its management. Himachal Journal of Agricultural Research 42: 47-51.

Zitikaite, I. and Samuitiene, M. 2009. Detection and characterization of cucumber mosaic virus isolated from sweet peppers. Sodinink. daržinink. 28: 281-88.

Zitikaite, I. and Staniulis, J. 2006. The use of RT-PCR for detection of viruses infecting cucumber. Agron. Res. 4: 471-74.

\section{How to cite this article:}

Tanvi, Anil Handa and Shelly Kapoor. 2020. Molecular Detection of Cucumber Mosaic Virus in Bell Pepper (Capsicum annuum L.). Int.J.Curr.Microbiol.App.Sci. 9(10): 1441-1447.

doi: https://doi.org/10.20546/ijcmas.2020.910.171 